\title{
Employee participation in France and Germany
}

by Frank Wooldridge

The author considers the positions taken by two countries which have always taken employee participation seriously

$\mathrm{T}$ he involvement of employees by such processes as giving information to, or the consultation of, such employees or their representation, and their participation, or that of their representative in decision making, takes place in a number of Member States of the EU. The intensity and methods of such participatory processes varies in different member states of the EU. Employee participation in France and Germany has been chosen for the purposes of the present article, because such participation has long been of importance in these countries. The phrase "employee participation" is sometimes used in this article to include information and consultation, as well as codetermination or participation in the strict sense. The present article will not consider the implementation of the European Works Council Directive in France and Germany. This Directive (OJ 1994, L254/64 amended by Directive 97/74/EC (OJ1998L10/22)) requires the establishment of a European Works Council, or a procedure for informing and consulting employees in the case of Community single undertakings or Community-scale groups of undertaking having at least 1,000 employees in the different member states and at least two establishments employing at least 150 persons in each of two member states.

The above Directive has had a considerable influence on the proposed Directive of the Council of Ministers and the European Parliament establishing a general framework for improving the information and consultation rights of employees in the European Community. This proposed Directive has recently been the subject of a successful conciliation procedure between the Council and the European Parliament, was adopted on 11 March 2002 (OJ 2002 L80/19). The Common Position adopted by this Council on 13 July 2001 may be found in the EU's Session Document C5-0388/2001 of 2 September 2001.

Employee representatives (délégués de personnel) were first introduced into France by a law of 24 June 1936. Works councils (comités d'enterprise) owe their origin to an Ordinance of 12 February 1945, which has been subsequently amended on a number of occasions. The third French institution which represents the interests of the employees, the trade union section (delegates) in the undertaking, owes its origin to a law of 27 December 1968. The French constitutional law of 27 October 1946, which is mentioned in the Constitution of 1958 , refers to the need for employees to participate in the management of the enterprise. However, in contrast to the position in Germany, there is no requirement under French law for employee participation at board level. The law of July 1 1986 did, however, provide for participation on the optional executive boards of public companies (sociétes anonymes). The position remains the same at present, under Article 225-27 of the latest version of the French Commercial Code.

Works councils have existed in Germany since the enactment of the Betriebsrätungsgesetz of 1920. They were reintroduced in Germany after the downfall of the Nazi regime by the Betriebsverfassungsgesetz (Works Councils Act of 1952), which has been extensively amended, especially by the Works Councils Act of 1972. Important amendments were also made in 2001, when a new Works Councils Act was published. Special rules apply to staff representation in the public sector. As far as works councils in the private sector are concerned, the law changed in 2001, to take account of alteration in methods of work and in technology. Trainees, external workers and employees using telephonic means of communication were included in the new definition of workers as also were persons working from home, whose principal work was for the establishment. In addition to German employees rights to be informed and consulted and to participate in certain decisions through the medium of the works council, German employees have the right to be represented on the supervisory boards of certain large companies. Three are three principal systems of such representation. The model in use in the coal, iron and steel industry is based upon a law of 1951 (MontanMitbestimmungsgesetz), that in enterprises of a certain type 
employing at least 500 employees is based upon paragraphs 76-77a, 81,85 and 97 of the Works Councils Act 1952, as amended, and that in certain enterprises employing at least 2,000 employees is based upon the Codetermination Act (Mitbestimmungsgesetz) of 1976. The present law relating to employees rights to information and to be consulted, as well as their rights of participation and codetermination are usefully considered in chapter 5 and 6 of the third edition of Weiss and Schmidt, Labour Law and Industrial Relations in Germany, Kluwer, 2000.

\section{THE POSITION IN FRANCE}

As already indicated, three separate institutions represent the interests of the employees in an undertaking, which will have one or more of these representative bodies depending on the size of the workforce, and on whether the trade unions so desire. The relevant representative bodies are the works council, the personnel representatives and the trade union representatives. The latter are very frequently members of the works council. Collective agreements very frequently provide to what might be called the free expression group, which is concerned with the manner of exercises of the collective right of freedom of expression regarding employment and conditions of employment, which is provided for by Article L461-1 of the Employment Case (Code du Travait).

In addition public companies may provide in their articles that representatives of the employees may sit on the executive board.

\section{Works councils}

According to Article L431-1 of the Employment Code undertakings of all kinds, including those engaged in the liberal professions and social security bodies (but with the expectation of certain public administrative bodies) which employ more than fifty persons for more than twelve months, whether consecutively or not, during the past three years, must establish a works council (comité d'enterprise). Elections take place every two years on the basis of lists of candidates which are submitted by trade unions only, and which correspond with the different categories of employees. However, different rules may be applicable where the undertaking has less than two hundred employees. These rules, are explained below. As in Belgium, the head of the undertaking (chefd'enterprise) is a member of the works council, and presides at meetings thereof. The works council also has union representatives. As in Germany, a central works council might be set up where the undertaking has a member of different establishments, in addition to the works councils required for each establishment. This requirement is contained in Article L435-1 of the Employment Code. A group of undertakings may likewise be required to set up a group works council in accordance with Article L439-1 et seq of the Employment Code.
The works council was intended to be a framework for communications between employers and employees, and was also designed to foster a closer relationships between them. It has an important role relating to the provision of information, and must be considered before certain important business decisions are taken.

Article L432-6 of the French Employment Code provides that in the case of companies (the French term is sociétés which includes general and limited partnerships as well as public and private companies), two delegates from the works council, one representing the technical and supervisory staff (agents de maîtrise), and the other the manual and clerical staff shall be entitled to attend all the meetings of the management or supervisory board. The number of delegates is increased to four in the special circumstance where there are three electoral colleges for the purpose of choosing personnel representatives: see Articles L432-6 and L433-2 of the Employment Code. The delegates from the works council are said by the second paragraph of Article L432-6 of the Employment Code to be entitled to the same documents as the directors.

According to Article L432-1 of the Employment Code, the works council must be informed of and consulted on questions of an economic nature concerning the organisation, management and general development of the undertaking and, in particular, on measures of a kind likely to affect the number or structure of the work force. It is also obligatory to consult the works council in good time on proposals to reduce the work force. Furthermore, Article L432-1 also provides that the works council must be informed of, and consulted on, modifications of the economic or legal organisation of the undertaking, especially in the event of mergers and transfers of the control of the company, and on important changes in the structure of the production of the enterprises, as well as on the acquisition or disposal of subsidiaries. Finally, Article L432-1 further provides that the works council must be informed of and consulted on situations in which the undertaking ceases to be able to pay its debts as they fall due, and in which it becomes subject to a process of judicial reorganisation. The provisions of Article L432-1 remind one of those of Article 4(2)(a)-(c) of the proposed Directive of the Council of Ministers and the EP which has been mentioned above, but they are much more detailed than those of the draft Directive.

It follows from Article L432-4 of the Employment Code that the works council has a right of access to and a right to consult similar documents to the shareholders. According to Article L225-231 of the new French Commercial Code, the works council may ask the president of the local commercial court, acting in summary proceedings, for the appointment of one or more experts in order to obtain independent advice on any business transaction decided on by a public 
company. If the president of the local commercial court deems it appropriate to appoint an expert, he determines his powers and renumeration. The experts' report is made available to the works council, the statutory auditors, the public prosecutor and the board of directors or executive board. According to Article L432-5 of the Employment Code in any undertaking, the works council may require information upon any matter of any kind that might prejudicially affect the business of the company. If no such information is given, or if the replies given indicate that there is cause for concern, the works council must prepare a report which must be communicated to the managers and the statutory auditors.

The powers granted to the works council described in the above paragraph do not find any parallel in the provisions of the Council and European Parliament Directive, which was enacted in 2002.

\section{Personnel representatives}

Such representatives must be elected where the workforce exceeds 10. The number of personnel representatives who are elected depends on the size of the workforce. Their principal function is the presentation of claims on behalf of the employees relating to employment regulations and rules (Employment Code, Article L422-1). The representatives are also empowered to communicate the suggestions and observations of the employees in matters within its competence to the works council. (Employment Code, Article L422-2 and L422-5) The personnel representatives have the right to take account of infringements of civil liberties in the undertaking and to contact the employer about them. The detailed rules are set out in Article L422-1-1. In undertakings having less than 200 employees, Article L431-1-1 of the Employment Code provides that the personnel representatives may form the employee delegation to the works council if the head of the enterprise so decides, and the works council and the personnel representatives are consulted in advance of this decision. Although, in such an event the two bodies have a similar composition, they will meet separately. In the absence of a works council (e.g. because of the lack of the necessary member of employees), the personnel representatives temporarily perform its economic functions (Employment Code, Article L431-3).

\section{Trade union delegations}

Such delegations (sections syndicales) must be selected in every enterprise having at least 50 employees. They are established by unions which are considered to be the most representative ones. Branches of the major unions treated as representative at the national level are irrebuttably presumed to be representative at the level of the establishment or enterprises. The delegations have the task of furthering the interests of trade union members, and they may engage in collective bargaining.

\section{Purposes of the different institutions}

The purposes of the three different kinds of representative institutions cannot be thought of as entirely distinct. Thus, for example, the works council will sometimes try to coordinate the work of the personnel representative(s) and the trade union delegation. This is possible because the trade unions have some influence on the composition of the works council, which is chaired by the head of the undertaking. Where there is no works council because the undertaking has insufficient employees, Article L431-3 makes it clear that the works council's economic functions will be temporarily performed by the personnel representative(s).

\section{Employee representatives on the boards of public companies}

According to Article 225-27 of the new Commercial Code, public companies (société anonymes, SAs) may provide in their articles that representatives of the company's employees will be members of the executive board. Such persons may be elected by the personnel of the company alone, or by such personnel and that if its direct and indirect subsidiaries, provided their registered offices (sièges social) are in France. The number of such directors must not be more than four, but may be increased to five in the case of companies whose shares are admitted to dealings on a regulated market. Directors who are elected by the employees must have a contract of employment with the company, or with one of its French direct or indirect subsidiaries which commenced more than two years before their nomination.

All the employees of the company, and in appropriate cases, of its direct or indirect French subsidiaries (whose registered offices are in France), who have been employed by the company for more than three months before the date of the election are eligible to vote, by secret ballot. The candidates or list of candidates may be proposed by one or more representative trade unions, or by over a twentieth of the electors, or if the number of employees is more than 2,000, by 100 of them (new French Commercial Code, Article L225-28).

The maximum period of office of employee directors is six years, which is renewable. Such directors must be shareholders, and they have the same rights, duties and liabilities as other directors. Their office may cease on the result of their dismissal from employment, their resignation as directors or employees, or their dismissal from office as director by a decision of the president of the civil court (tribunal de grande instance) acting in summary proceedings, on the request of the majority of the directors (new French Commercial Code, Article L22532). 


\section{THE POSITION IN GERMANY}

\section{Works councils}

According to paragraph 1of the Works Council Act 2001, any establishment with more than five employees over the age of 18 of whom at least three have been employed there or at least six months is required to establish a works council. The same is true of a common establishment belonging to more than one undertaking which fulfils these conditions. However, it is left to the employees of the relevant establishment to decide whether they wish to hold an election. Many small establishments fail to comply with the mandatory requirements of law governing the establishment of a work council. Although works councils are separate from trade unions, their members are generally members of trade unions. If works councils exist in different establishments of an enterprise, these works councils must form a common works council (Gesamtbetriebsrat). (Works Councils Act 2001, paragraph 47). If an enterprise belongs to a group of companies, a group works council may be formed (Works Councils Act 2001, paragraph 54 et seq). In practice, such Konzernbetriebsräte are of little significance (see Weiss and Schmidt, Labour Law and Industrial Relations in Germany, 3rd ed., Kluwer 2000, p.149).

The term of office of works council members is four years, and they may be re-elected. Candidates may be proposed by trade unions which have at least one member in the establishment, or by one-twentieth of the employees entitled to vote or at least three thereof. The size of the works council depends on the number of employees in the undertaking. Persons over the age of 18 who have worked in the establishment for six months are eligible for election. This takes place by a system of proportional representation, unless only one electoral proposal is made, or the simplified electoral procedure applicable to small establishments employing between 550 persons is used, and a simple majority vote takes place. The works council is required to include members of both sexes, white collar and manual workers, and workers from different departments and pursuing different activities of the undertaking (Works Councils Act 2001, paragraph 15). The executive staff, as defined in paragraph 5 of the Works Council Act 2001 neither participates in the election of works council members, nor may they become members of the works council. However an Act of 1989 permits the election of a separate body for such staff.

As in the Netherlands, works council members are entitled to be released from their duty to work without loss of pay to the extent necessary for properly carrying out their duties account being taken of the nature and size of the establishment. In establishments which employ at least 100 persons, the works council must appoint an economic committee and may appoint other committees and confer particular tasks on them. The works council of such an establishment can also entrust groups of workers with specific tasks.
The works council has a number of rights which extend from a simple right to information and to be consulted to a right of veto and codetermination. The right to codetermination is of much importance in relation to social matters: paragraph 87 of the Act enumerates 12 such matters, for example the length of the working day and provisions for the prevention of accidents at work. As far as certain economic matters (for example a merger or transfer of the undertaking) are concerned, the right of the works council to be informed and consulted are vested in the economic committee; there is no right to codetermination concerning such matters. However, the works council has important participatory rights in relation to certain specific economic decisions involving a substantial alteration to the establishment which might cause significant hardship to its workforce, provided that such establishment employs at least 20 persons (Works Council Act 2001; paragraph 111). Codetermination is of little significance in personnel matters.

Conflicts which arise between management and the works council may, and must in some cases be referred to a conciliation board (Einigungstelle). Such a reference may be made where management and the works council are unable to agree on whether and how measures envisaged by the management in the case of a substantial alteration to the establishments have to be carried out.

\section{Significance of the unions}

Many works council members are also members of a union. Such unions have an initiating function, calling a works meeting in an establishment without a works council which decides whether or not such a council shall be established. The unions play a significant role in controlling the works council election procedure, and should legal rules be violated, a union may obtain a court decision nullifying the election. In large companies, unions frequently have their trusted representatives (Vertrauensleute) who form a link between the members of the union and its administration, and have an important influence on the works council activities.

\section{Employee representation on the supervisory board}

The supervisory board has considerable powers in German public companies. It thus exercises control over the management board, has an extensive right to information from it, can appoint the directors, and has important functions in relation to the accounts. Private companies are not normally required to have a supervisory board, but they may set up one on a voluntary basis. Large private companies which are subject to the three major codetermination laws discussed below are required to have a supervisory board; these laws extend rather similar provisions of the law governing public companies to them. In both public and private companies the management board (or managers) are responsible both for the management and representation of the company 
The double board system dates from the nineteenth century.

\section{Codetermination in the coal, iron and steel industry}

As already indicated, there are three principal systems of employee participation in Germany. The model used in the coal, iron and steel industries involves the equal representation of shareholders and employees on the supervisory board, the neutral chairperson being elected by the majority vote of the shareholders and the employees representatives (Coal, Iron and Steel Codetermination Act 1951, as amended, paragraph 8). The coal, iron and steel Codetermination Act applies to public and private companies and to incorporated cost book companies (bergrechtlichen Gewerkschaften) employing more than 1,000 persons (Codetermination Act 1951, as amended, paragraph 1(2)). The supervisory board will have at least eleven members, which will be increased to 15 or 21 in very large companies (paragraphs 4 and 9, ibid). At least two of the employee representatives must belong to the workforce of the company. Two out of the three remaining members may, and generally do, belong to unions represented in the enterprise, but the third member may not belong to a trade union, or have a service agreement with or be an employee of, the enterprise, or have significant interests in it (paragraph $4(2), i b i d)$. The workers' representatives are nominated together. Before such nomination takes place, the unions which are active in the enterprise and their executive organisations must be consulted (paragraph 6(1), ibid). Assuming that the supervisory board has eleven members, proposals regarding the remaining three seats (i.e. that of the remaining two employee representatives and that of the additional member) will be made by the trade unions represented in the undertaking. Nominations will be made by secret ballot, and the persons nominated will be elected and confirmed in office by the general meeting, which is bound by the nominations made. The same rule will apply if the number of seats to be filled is more than 3 (paragraphs 6(3) - 6(6), ibid.) In companies subject to the system of codetermination of the coal, iron and steel industries, the Act of 1951, as amended, provides for employee representation on the executive board in the form of an employee director, responsible for labour and social affairs. Such a director cannot be appointed or dismissed against the majority of votes of the employee representatives on the supervisory board (paragraph 13(1), ibid.)

\section{Codetermination in certain holding companies}

Coal, iron and steel holding companies are subject to the special system of employee representation provided for in the Montan-Mitbestimmunesergänzungsgesetz of 1956, as amended. According to paragraph 3(2) of the statute, a controlling company is subject to this Act if the controlling company's turnover (account being taken of the relevant costs of raw and operational materials and of services performed by third parties) from activities in the coal, iron and steel industries amount to one-fifth of its total turnover, or if at least 2,000 of the employees of the group are employed in the latter industries. The constitutionality of the requirement as to the number of employees (but not of that relating to turnover) has been denied by the Constitutional Court in a case which it belatedly decided in 1999 (B Verf G.99,367). The court held that this requirement violated Article 3(1) of the Federal Constitution which provides that all persons are equal before the law. The requirement as to the number of employees was capable of including largeenterprises which did not carry out sufficiently meaningful activities in the coal, iron and steel industry. It appears that paragraph 3(2) may be amended in the fairly near future (see Weiss and Schmidt), op.cit. p.214), but no amendment was made to it by the new Works Councils Act of 2001 .

\section{Codetermination in accordance with the Works Councils Act, 1952}

It is interesting to note that the relevant provisions of the 1952 Act regarding codetermination, i.e. paragraphs 76-77a, 81,85 and 87 thereof, are the only provisions of this Act which remain in force. The Act is limited to public and private companies, limited partnerships with shares, incorporated cost book companies, cooperatives and mutual insurance companies. The entity in question must employ at least 500 persons. If it does so, one third of the members of the supervisory board must be representatives of the employees. According to paragraph 76(2), if one employee representative has to be elected, that person must be in the employ of the company. Should it be necessary to appoint two or more representatives, at least two of these must consist of employees of the enterprise. Employee representatives are elected by all the employees of the enterprise over the age of 18. According to paragraph 76(3) of the Works Councils Act, nominations must be made by the works councils, and by one-tenth of the employees of the enterprise, or at least 100 employees.

\section{Codetermination under the 1976 Act}

The above Act applies to public and private companies, limited partnerships with shares, incorporated cost book companies and cooperatives which regularly employ more than 2,000 persons. If an entity of one of the former kinds is the controlling company in a group, then the employees of the subsidiary companies are taken into account together with those of the controlling company for the purpose of determining whether the Codetermination Act 1976 applies to the latter company (paragraph 5(1), ibid). The 1976 Act provides for an equal number of representatives of employers and employees. The actual size of the supervisory board is dependent on the number of employees, (paragraph 7(1), ibid). If the board has six or eight employee representatives, two of these seats must be reserved for trade union representatives. If the number 
of employee representatives on the supervisory board is 10 , the relevant number of trade union representatives is increased to three (paragraph 7(2), ibid. The remaining seats on the supervisory board are reserved for employees of the enterprise; they are distributed between workers, and executive staff (Leitender Angestellter). The executive staff are defined in the same way as in paragraph 5(3) of the Works Council Act 1972 (as amended). The distribution of seats depends on how the three categories of workers are represented in the undertaking, but if a category is represented at all it must have at least one seat on the supervisory board (paragraph 15(2) ibid.).

The method of election of employee representatives is very complex. There are basically two types of election. If an undertaking employees more than 8,000 persons, the election takes place through the medium of delegates, unless the employees who are entitled to vote decide on direct elections. If the undertaking has less than 8,000 employees, direct elections take place, unless those employees who are qualified to vote decide that it shall take place through the medium of delegates (paragraph 8(1) and (3) ibid.). A vote on the question whether the election is to take place through the medium of a direct vote or through that of delegates must be requested by a motion signed by one-twentieth of the workforce of the undertaking. The ballot is secret. The relevant decision must be taken by at least one half the workforce eligible to vote (paragraph 9(3), ibid.). Whether an election of workers representatives is by delegation or is direct it takes place by a secret vote of all the categories of delegates of workers (including the executives). At least one executive must be appointed to the supervisory board. Voting is by a system of proportional representation, unless one nomination is made when the representatives are chosen by a majority vote. In such an event, the number of candidates must be twice the number of seats vacant for workers and executives representatives, (paragraphs 15 and 18, ibid.). The trade union representatives mentioned in paragraph 7 of the 1976 Act are also elected by a system of proportional representation. There is a secret ballot of delegates representing the workers who are joined by the executives (paragraph 16(1), ibid. The candidates may be nominated by the trade unions which are represented in the undertaking or in other undertakings which belong to the same group as the controlling undertaking and who participate in the choice of the members of the latter undertaking's supervisory board (paragraph $5, \mathrm{ibid}$.). If only one nomination is made, the trade union representatives are chosen by a majority vote rather than by proportional representation. Once again the number of candidates nominated must be twice that of the number of vacant seats (paragraph 16(2), ibid). Both in direct elections and elections by delegates, the employees are entitled to reject any proposed union candidate (Weiss and Schmidt, op.cit., p.217).

Most decisions of the supervisory board require a simple majority. However a two-thirds majority is required in the cases set out in paragraphs 27 and 29 of the 1976 Act. By paragraph 27 of this Act, the chairperson of the supervisory board is elected by a two third's majority of the members. If such a majority cannot be obtained, the shareholders' representatives elect the chairperson and the employees' representatives the vice chairperson. This rule explains why the chairperson is generally a representative of the shareholders, such that the Act cannot really be said to have created equal or paritative codetermination, because the chairperson has a casting vote if the first vote is tied (paragraph 29(2), ibid.). This casting vote cannot be exercised by the vice chairperson but it may be exercised by a member of the supervisory board duly authorised by the chairperson, if he or she is unable to attend the meeting.

\section{Constitutionality of the Codetermination Act 1976}

Objections have been made to the system of codetermination introduced by the 1976 Act on the grounds that it may discourage investment, increase the powers of trade union officials and result in conflicts at the level of the supervisory board. It has also been contended that it may sometimes go beyond equal or paratative codetermination in its effect. There has also been controversy about the constitutionality of the Codetermination Act, but this would seem to be less significant since the Constitutional Court has found the Act to be constitutional in its decision of 1 March 1979 (B Verf G50, 290). The complaint that the Act was unconstitutional was made on several grounds, the most important of which seem to have been that it violated the guarantee of private property contained in Article 14 of the Federal Constitution and also violated Article 9(3) of that Constitution. The latter provision stipulates inter alia that the right to form associations for the purpose of protecting and enforcing employment and business conditions is guaranteed for everyone, and for all associations. It is treated by commentators as requiring the strict separation of employers and employees in the collective bargaining process (Tarifautonomie: See Hesse, Grundzuge des Verfassungsrechts, 20th ed., pub. Müller, 1995, p.180). The guarantee of private property was alleged to be infringed because it was argued that investors could not longer use their invested capital in the way in which they wished to.

The Constitutional Court rejected the arguments based upon the two above provisions, and also upon the other constitutional provisions cited by those who made the constitutional complaints. As far as the complaints based upon Article 9(3) were concerned, the Court found that although the Codetermination Act 1976 resulted in the mutual dependence of the shareholders and employees representatives on the supervisory board, these parties were different from those to a collective agreement which were usually employers associations and unions. It should be noted that the independence of the parties to collective 
agreements may arguably be compromised by the continuous process of compromise and negotiation which takes place at supervisory board level. The approach taken by the employees' representatives (who will usually be union members) on the supervisory board will clearly have some affect on the employers associations. The Court did not however think that this pragmatic fact was enough to compromise the independence of the two negotiating parties.

Although private property is guaranteed by the first sentence of Article 14(1) of the Constitution, the second sentence of that provision stipulates that the contents of this right and limitations thereon may be prescribed by law. Article 14(2) stipulates that property involves obligations, and its use should also serve the public good. The Constitutional Court took the view that Article 14(1) protects the substance of property rights, and that limitations thereon must comply with the principle of proportionality. It had no difficulty in finding that the ownership of shares conferred, both as far as the membership rights and the rights the assets it gave rise to were concerned, a kind of indirect ownership arising through the medium of company law. Limitations on such ownership existed insofar as the shareholder was unable to make direct use, or dispose of it. The use of such right of ownership was limited by the principle of majority rule.

The Court found that the relevant provisions of the Codetermination Act 1976 were a restriction placed upon the use of property, which served the public good. It found that because it followed from paragraph 27(2) and 29(2) of the Codetermination Act 1976 that the ultimate decisions of the supervisory board remained within the power of the shareholders representatives, the property rights of the shareholders were sufficiently guaranteed. The Court also pointed out that the Codetermination Act of 1976 did not meaningfully restrict the value of the shares, on the prospective yield on them.

The Constitutional Court found that the 1976 Act did not establish a system of paritative codetermination, because of the casting vote of the shareholders' representative on the supervisory board. It also emphasised that there was no form of codetermination in the other organs of the company, the management board and the general meeting.

It is not clear from the judgement of the Constitutional Court whether a system of genuinely equal or paritative codetermination at the level of the supervisory board would be constitutional. It must be remembered that it exists both in the legislation of 1951 and 1956 relating respectively to codetermination in coal, iron and steel companies and in coal, iron and steel companies and in coal, iron and steel holding companies.

\section{CONCLUSION}

The French and German legislation on employee participation is more detailed than that contained in the framework Directive for informing and consulting employees in the European Community, which was recently enacted. The Directive would seem likely to have a greater effect in countries such as the United Kingdom and Italy, where there are few works councils or analogous bodies: in the United Kingdom, shop stewards and in Italy representative bodies connected with the unions, functioning at the level of the undertaking engage in collective bargaining. Works councils have sometimes been set up in these countries on a voluntary basis or in accordance with the 1994 Directive on European Works Councils, which was amended in 1997.

The detailed implementation of the framework Directive is left to the member states, which will be allowed to adapt the principles, definitions and arrangements contained therein to their national situation. The Directive does not make use of the term works council, but it requires arrangements to be made at a national level for informing and consulting employees in undertakings employing at least 50 persons, or in establishments employing at least 20 persons, in a member state. Such arrangements would seem most usually likely to take place through the medium of a works council, or through that of a body akin to the French personnel representatives, who are not parallel by any corresponding German body.

Germany has gone much further than France insofar as employee participation at board level is concerned. This may be in part due to the existence of the dual board system in Germany. The differing three systems of employee participation at board level in that country owe their existence to historical and political circumstances. The new Directive on the information and consultation of employees does not mention employee participation at board level.

The Council Regulation on the European Company Statute was adopted on 8 October 2001 (OJ L294/1, 10 November 2001), together with a Council Directive on the supplementing of the statute by the involvement of employees. The enactment of this instrument, which came into force on the date of its publication in the Official Journal, may encourage the Commission to do further work on employee participation in companies generally, but it does not contain original rules governing employee paticipation.

Frank Wooldridge 